\title{
Wujud Peralihan Kode dalam Peristiwa Tutur Informal Masyarakat Multietnis di STKIP Singkawang Kalimantan Barat
}

\author{
Heru Susanto $^{1)}$, B. Wahyudi Joko Santoso ${ }^{2)}$ \\ 1. Program Studi Pendidikan Bahasa dan Sastra Indonesia, STKIP Singkawang, \\ E-mail: anto_eru@yahoo.co.id \\ 2. Pascasarjana Universitas Negeri Semarang, \\ E-mail:wahyudibsa@gmail.com
}

\begin{abstract}
Abstrak. Keberagaman etnis pada masyarakat multilingual di STKIP Singkawang dapat mengakibatkan adanya kontak bahasa. Masing-masing etnis yang berada di lingkungan sekolah tinggi tersebut memiliki kode tutur yang berbeda-beda. Perbedaan kode tutur tersebut akan dapat memengaruhi jalannya proses pertuturan. Hal inilah yang terjadi pada masyarakat multilingual di STKIP Singkawang Kalimantan Barat. Masyarakat multilingual di STKIP Singkawang terdiri dari dua etnis besar, yaitu etnis Melayu Sambas dan etis Dayak Kanayatn dan dua etnis kecil, yaitu etnis Jawa dan Madura. Tujuan penelitian ini adalah menemukan dan menjelaskan wujud alih kode dan menemukan dan menjelaskan faktor-faktor alih kode. Data dalam penelitian ini adalah penggalan tuturan pada tuturan informal masyarakat multilingual di STKIP Singkawang. Data dikumpulkan melalui dua metode yaitu, metode simak dan metode cakap. Metode simak menggunakan teknik dasar yaitu teknik sadap. Teknik lanjutan dari metode simak dalam penelitian ini adalah simak bebas libat cakap, teknik rekan dan teknik catat. Selanjutnya, untuk metode cakap menggunakan teknik dasar yaitu teknik pancing. Teknik lanjutan dari metode cakap yaitu, teknik cakap semuka, teknik rekam dan teknik catat. Untuk menganalisis data dalam penelitian ini menggunakan metode padan dengan alat penentu adalah bahasa lain. Simpulan dari penelitian mengenai alih kode dan campur kode pada tuturan informal masyarakat multilingual di STKIP Singkawang adalah sebagai berikut. Wujud alih kode yaitu alih kode internal. Alih kode internal yang terjadi adalah alih kode dari kode tutur Melayu Sambas ke kode tutur Indonesia, alih kode dari kode tutur Dayak Kanayatn ke kode tutur Indonesia, dari kode tutur Indonesia ke kode tutur Melayu Sambas, dan dari kode tutur Indonesia ke kode tutur Dayak Kanayatn. Kemudian untuk faktor-faktor penyebab alih kode terdiri dari lima faktor yang menjadi penyebab timbulya alih kode. Adapun kelima faktor tersebut meliputi (1) penutur, (2) mitra tutur, (3) hadirnya orang ketiga dalam pertuturan, (4) pokok pembicaraan, dan (5) untuk membangkitkan rasa humor.
\end{abstract}

Kata Kunci : alih kode, peristiwa tutur informal, masyarakat multietnis.

\section{PENDAHULUAN}

Peristiwa kontak bahasa sering terjadi pada masyarakat multilingual. Kontak bahasa lebih banyak dipengaruhi oleh latar belakang etnis dan juga bahasa yang berbeda-beda. Hal tersebut senada dengan pendapat Matras (2009:1) mengatakan "language contact occurs when speakers of different languages interact and their languages influence each other". Artinya kontak bahasa terjadi ketika pembicara atau penutur dari bahasa-bahasa yang berbeda berinteraksi dan bahasa tersebut memengaruhi satu sama lain.

Latar belakang etnis yang beranekaragam seperti pada masyarakat Indonesia menuntut pengguna bahasa dapat menguasai bahasa Indonesia sebagai sarana untuk berinteraksi dalam rangka komunikasi sehari-hari. Dalam rangka pemenuhan kebutuhan hidup, tentunya setiap orang akan berkomunikasi dengan orang lain meskipun dari latar belakang etnis yang lain. Komunikasi antar kelompok masyarakat tidak akan berjalan efektif apabila mereka hanya menguasai bahasa daerah mereka sendiri. Orang Melayu Sambas misalnya hanya menguasai kode tutur Melayu Sambas atau orang Dayak Kanayatn hanya mengusai kode tutur Dayak Kanayatn saja, mereka akan merasa kesulitan berkomunikasi dengan orang-orang yang tidak mengusai kode tutur mereka. Keadaan seperti inilah Bahasa Indonesia dapat berkembang sesuai dengan fungsi dan kedudukannya sebagai Bahasa Negara Republik Indonesia (UUD, 1945).

Bahasa adalah sistem tanda bunyi yang disepakati untuk dipergunakan oleh enggota masyarakat tertentu dalam bekerja sama, berkomunikasi, dan mengidentifikasikan diri (Kridalaksana, 2005). Menurut Chomsky (1957:13) "language is a set of sentences, each finite length and 
contructed out of a finite set of elementsk" artinya Bahasa adalah seperangkat kalimat, masing-masing panjang terbatas dan dikonstruksi dari sebuah himpunan berhingga (Chomsky, 1957). Bahasa merupakan sistem lambang berupa bunyi yang bersifat sewenang-wenang (arbitrer) yang dipakai oleh anggota-anggota masyarakat untuk saling berhubungan dan berinteraksi (Sumarsono, 2007).

Sekolah Tinggi Keguruan dan Ilmu Pendidikan (STKIP) Kota Singkawang merupakan gambaran yang tepat untuk menggambarkan situasi masyarakat yang mulilingual dikarenakan latar belakang etnis mahasiswanya yang beragam. Mahasiswa di STKIP Singkawang terdiri dari dua etnis besar, yaitu etnis Melayu Sambas dan etnis Dayak Kanayatn serta dua etnis kecil yaitu etnis Jawa dan Etnis Madura. Secara georgrafis STKIP Singkawang merupakan wilayah yang strategis, yaitu sebagai kota transit menuju daerah lain seperti Kabupaten Sambas dan juga Kabupaten Bengkayang. Kota Singkawang juga merupakan daerah lintas negara yang menghubungkan negara Indonesia dengan negara tetangga, yaitu negara Malaysia. STKIP Singkawang merupakan satu-satunya perguruan tinggi keguruan yang ada di tiga wilayah kabupaten/kota tersebut. Berdasarkan hal tersebut mahasiswa di STKIP Singkawang sebagian besar berasal dari tiga wilayah tersebut. Mahasiswa yang berasal dari Kabupaten Sambas (MEMS) dalam berkomunikasi biasa menggunakan kode tutur Melayu Sambas, kemudian mahasiswa yang berasal dari Kabupaten Bengkayang MEDK) dalam berkomunikasi biasa menggunakan kode tutur Dayak Kanayatn. Sedangkan mahasiswa yang berasal dari Kota Singkawang sendiri ada yang menggunakan kode tutur Melayu Sambas dan juga kode tutur Dayak Kanayatn dan juga sebagain kecil menggunakan kode tutur jawa dan kode tutur madura. Di samping itu mereka juga menggunakan kode tutur Indonesia sebagai sarana mereka berkomunikasi di antara mereka.

Berdasarkan latar belakang etnis yang beragam, terdapat permasalahan komunikasi di antara para penuturnya yang berlatar belakang etnis belainan. Permasalahan utama yaitu adanya kontak bahasa yang terjadi pada masyarakat multilingual di sekolah tinggi tersebut. Peristiwa kontak bahasa akan memyebabkan adanya pilihan kode tutur, karena masing-masing penutur berlatar belakang etnis yang berlainan. Definisi kode yaitu, sebagai sebuah sistem yang digunakan untuk berkomunikasi antara dua penutur atau lebih yang berupa bahasa tertentu (Wardhaugh, 1986). Pilihan kode tutur di antara masyarakat multilingual yang terdapat di STKIP Singkawang akan menentukan kualitas komunikasi di antara mereka. Selain pilihan kode tutur dan pencampuran kode tutur, adanya dua etnis yang mayoritas dan dua etnis minoritas yang ada di lingkungan kampus tersebut juga akan memunculkan adanya kekuasaan dan solidaritas dalam pertuturan. Hal ini akan menarik untuk dikaji apakah dua etnis yang mayoritas tersebut akan mendominasi pertuturan yang terjadi, atau akan menunjukkan rasa solidaritasnya dalam pertuturan di antara mereka.

Berdasarkan hal di atas, di dalam masyarakat yang multilingual seperti yang terjadi di lingkungan STKIP
Singkawang tersebut harus ada strategi untuk mengatasi kendala komunikasi lintas etnis khususnya pada ranah pergaulan informal. Salah satu strategi untuk mengatasi hal tersebut adalah dengan alih kode dan campur kode. Alih kode adalah peristiwa peralihan dari kode yang satu ke kode yang lain (Suwito, 1985). Dari pengertian tersebut dapat dimisalkan seperti peralihan dari kode tutur Melayu Sambas ke kode tutur Indonesia atau juga sebaliknya. Aspek lain dari saling ketergantungan bahasa dalam masyarakat multilingual ialah terjadinya gejala campur kode. Suwito (1985:76) mengutip pendapatnya Thelander menjelaskan bahwa gejala campur kode adalah apabila di dalam suatu tuturan terjadi percampuran atau kombinasi antara variasi-variasi yang berbeda di dalam satu klausa yang sama. Dapat dimisalkan seperti pencampuran dari kode Melayu Sambas ke kode Indonesia atau juga sebaliknya.

Penelitian ini menempatkan pada salah satu ranah yaitu alih kode dan campur kode pada tuturan informal. Dipilihnya ragam informal karena dalam ragam informal peristiwa alih kode dan campur kode akan sangat beragam. Hal ini sesuai dengan pendapat Gumperz (1977) yang menyatakan bahwa peristiwa alih kode lebih sering terjadi dalam percakapan informal. Berdasarkan pendapat tersebut dipilihnya peristiwa tutur pada ragam informal sesuai untuk mengungkap keanekaragaman wujud-wujud alih kode dan campur kode pada masyarakat multi etnis di STKIP Singkawang Kalimantan Barat.

\section{METODE}

Penelitian ini menggunakan metode deskriptif kualitatif. Metode kualitatif sering disebut metode penelitian naturalistik karena penelitiannya dilakukan pada kondisi yang alamiah (Sugiono, 2015). Penelitian deskriptif kualitataif mengarah pada pendeskripsian secara rinci dan mendalam tentang potret kondisi tentang apa yang sebenarnya terjadi menurut apa adanya di lapangan studinya (Sutopo, 2002). Latar tempat pada penelitian ini adalah di Sekolah Tinggi Keguruan dan Ilmu Pendidikan (STKIP) Singkawang di Kota Singkawang, Provinsi Kalimantan Barat. Alamat lengkap STKIP Singkawang yaitu Jalan STKIP, Kelurahan Naram Kecamatan Singkawang Utara, Kode Pos 79251 Kalimantan Barat.

Data dalam penelitian ini adalah penggalan tuturan pada peristiwa tutur informal masyarakat multilungual di STKIP Singkawang. Sedangkan sumber data dalam penelitian ini adalah berbentuk tuturan. Data dikumpulkan melalui dua metode yaitu, metode simak dan metode cakap. Metode simak menggunakan teknik dasar yaitu teknik sadap. Teknik lanjutan dari metode simak dalam penelitian ini adalah simak bebas libat cakap, teknik rekan dan teknik catat. Selanjutnya, untuk metode cakap menggunakan teknik dasar yaitu teknik pancing. Teknik lanjutan dari metode cakap yaitu, teknik cakap semuka, teknik rekam dan teknik catat. Untuk menganalisis data dalam penelitian ini menggunakan metode padan dengan alat penentu adalah bahasa lain (Sudaryanto, 2015) 


\section{HASIL DAN PEMBAHASAN}

1. Hasil

Berdasarkan hasil penelitian mengenai wujud alih kode pada peristiwa tutur informal masyarakat multilingual di STKIP Singkawang, yaitu pada wujud alih kode internal. Alih kode internal yang terjadi adalah alih kode dari kode tutur Melayu Sambas ke kode tutur Indonesia, alih kode dari kode tutur Dayak Kanayatn ke kode tutur Indonesia, dari kode tutur Indonesia ke kode tutur Melayu Sambas, dan dari kode tutur Indonesia ke kode tutur Dayak Kanayatn. Kemudian untuk faktor-faktor penyebab alih kode terdiri dari lima faktor yang menjadi penyebab timbulya alih kode. Adapun kelima faktor tersebut meliputi (1) penutur, (2) mitra tutur, (3) hadirnya orang ketiga dalam pertuturan, (4) pokok pembicaraan, dan (5) untuk membangkitkan rasa humor

2. Pembahasan

Dalam sub bab ini akan dijelaskan mengenai wujud alih kode pada peristiwa tutur informal masyarakat multilingual di STKIP Singkawang. Adapun penjelasan berdasarkan hasil temuan sebagai berikut.

a. Wujud Alih Kode

Wujud alih kode internal berdasarkan hasil penelitian yang telah dilakukan nampak pada data berikut. Pada hari Rabu, 10 Maret 2017 pukul 12.00 WIB siang hari terjadi percakapan antara tiga orang mahasiswa di Kantin Kampus STKIP Singkawang. Dua orang mahasiswa berasal dari etnis Dayak Kanayatn dan satu orang mahasiswa berasal dari etnis Melayu Sambas.

KONTEKS : PADA HARI JUMAT 10 MARET
2017, SEKITAR PUKUL 12.00 WIB
DI KANTIN KAMPUS TERJADI
PERTUTURAN ANTARA DUA
ORANG MAHASISWA YANG
BERASAL DARI ETNIS DAYAK
KANAYATN DAN SATU ORANG
MAHASISWA BERASAL DARI
ETNIS MELAYU SAMBAS,
MEREKA MEMBICARAKAN
PERIHAL PEKERJAAN DAN
KEMAJUAN KULIAH MEREKA.

MEMS : Berhenti kerja kah Yung?

MEDK 1 : Aoklah. 'Tyalah.'

MEMS : Masih ada rezeki di tempat lain, yakin lah.

MEDK 1 : Iyelah, amin.'Iyalah, amin'

MEDK $2 \quad$ : Sidangkah besok Yung?

MEDK 1 : Aok. Kau dah daftarmeh? 'Iya. Kau sudah daftarkah?

MEDK 2 : Repo, nape aku. 'Senang kamu, belum aku.'
MEDK 1 : Apanya yang senang, ngorbankan kerjaan. 'Apanya yang senang, ngorbankan kerjaan.'

Penggalan tuturan data di atas terjadi di kantin kampus STKIP Singkawang pada hari Jumat 10 Maret 2017. Penggalan tuturan tersebut terjadi antara tiga orang mahasiswa yang berasal dari satu orang mahasiswa etnis Melayu Sambas berjenis kelamin perempua dan dua orang mahasiswa etnis Dayak Kanayatn berjenis kelamin laki-laki. Ketiga orang mahasiswa tersebut membicarakan perihal pekerjaannya dan kemajuan kuliah mereka. Adapun metode yang digunakan untuk menentukan wujud alih kode pada penggalan tuturan tersebut adalah metode padan translasional alatnya adalah bahasa lain dengan teknik hubung banding menyamakan (HBS). Hal ini dilakukan untuk membandingkan data yang ada, sehingga ditemukan wujud alih kode yang dapat diuji secara ilmiah.

Pada penggalan tuturan di atas terjadi alih kode dari kode tutur Dayak Kanayatn ke kode tutur Indonesia. Pada awalnya mahasiswa etnis Dayak Kanayatn 2 bertanya kepada mahasiswa etnis Dayak Kanayatn 1 menggunakan kode tutur Indonesia yaitu Sidang kah besok Yung?. Namun, pada tuturan selajutnya beralih kode menggunakan kode tutur Dayak Kanayatn yaitu, repo nape aku?. Jika mahasiswa etnis Dayak Kanayatn 1 tetap menggunakan kode tutur Indonesia menjadi Senang kamu, belum aku. Hal ini merupakan bentuk penerapan dari teknik hubung banding menyamakan (HBS), artinya kode tutur Dayak Kanayatn yang digunakan dalam alih kode penggalan tuturan di atas disamakan dengan kode tutur Indonesia. Penggalan tuturan di atas termasuk dalam alih kode internal dikarenakan penutur beralih kode dari kode kedaerahan ke kode nasional.

Wujud alih kode internal berdasarkan hasil penelitian yang telah dilakukan nampak pada data berikut. Pada hari Senin, 13 Maret 2017 pukul 14.00 WIB siang hari terjadi percakapan antara tiga orang mahasiswa di Kantin Kampus STKIP Singkawang. Dua orang mahasiswa berasal dari etnis Dayak Kanayatn.

KONTEKS : PADA HARI SENIN 13 MARET 2017, SEKITAR PUKUL 14.00 WIB DI KANTIN KAMPUS TERJADI PERTUTURAN ANTARA DUA ORANG MAHASISWA YANG BERASAL DARI ETNIS DAYAK KANAYATN, MEREKA MEMBICARAKAN PERIHAL KEMAJUAN STUDI MEREKA.

MEDK 1 : Nyamanlah kau dah maok sidang. Nyamanlah kamu sudah mau sidang.'

MEDK 2 : Nyaman ihan Lan, aku sidang karajo baranti nadeo. 'Nyaman apa Lan, aku sidang kerja berhenti selamanya.' 
MEDK 1 : Tapikan dah maok aka ugak kuliah nyamanlah. 'Tapikan sudah mau selesai kuliah. Nyamanlah.'

MEDK 2 : Amin, doakan lancar ya.

MEDK 1 : Aok. 'Tya.'

Penggalan tuturan data (08) di atas terjadi di kantin kampus STKIP Singkawang, pada hari Senin, 13 Maret 2017. Peserta tutur pada penggalan tuturan tersebut antara dua orang mahasiswa yang berasal dari satu etnis yaitu etnis Dayak Kanayatn berjenis kelamin laki-laki dan perempuan. Kedua orang mahasiswa tersebut membicarakan perihal kemajuan kuliah mereka. Adapun metode yang digunakan untuk menentukan wujud alih kode pada penggalan tuturan tersebut adalah metode padan translasional alatnya adalah bahasa lain dengan teknik hubung banding menyamakan (HBS). Hal ini dilakukan untuk membandingkan data yang ada, sehingga ditemukan wujud alih kode yang dapat diuji secara ilmiah.

Pada penggalan tuturan di atas terjadi alih kode dari kode tutur Dayak Kanayatn ke kode tutur Indonesia. Pada awalnya mahasiswa etnis Dayak Kanayatn 2 menggunakan kode tutur Dayak Kanayatn yaitu Nyaman ihan Lan, aku sidang karajo baranti nadeo. Tuturan tersebut merupakan dari respon dari pertanyaan mitra tutur sebelumnya. Namun, pada akhir percakapan mahasiswa etnis Dayak Kanayatn 2 beralih kode menggunakan kode tutur Indonesia yaitu, Amin, doakan lancar ya. Jika mahasiswa etnis Dayak Kanayatn 2 tetap menggunakan kde tutur Dayak menjadi Amin, doaant lancar boh. Hal ini merupakan bentuk penerapan dari teknik hubung banding menyamakan (HBS), artinya kode tutur Indonesia yang digunakan dalam alih kode penggalan tuturan di atas disamakan dengan kode tutur Dayak Kanayatn. Penggalan tuturan di atas termasuk dalam alih kode internal dikarenakan penutur beralih kode dari kode kedaerahan ke kode nasional.

\section{b. Faktor Alih Kode}

Faktor penyebab alih kode yang disebabkan oleh hadirnya orang ketiga terdapat pada data berikut. Pada data tersebut terjadi percakapan antara tiga orang mahasiswa di aula STKIP Singkawang pada hari Senin, 10 April 2017 sekira pukul 13.00 WIB. Dua orang mahasiswa berasal dari etnis Dayak Kanayatn dan satu mahasiswa berasal dari Melayu Sambas.

KONTEKS : PADA HARI SENIN, 10 APRIL 2017, SEKITAR PUKUL 13.00 WIB DI AULA KAMPUS TERJADI PERTUTURAN ANTARA DUA ORANG MAHASISWA YANG BERASAL DARI ETNIS DAYAK KANAYATN DAN SATU ORANG MAHASISWA BERASAL DARI ETNIS MELAYU SAMBAS,
MEREKA MEMBICARAKAN PERIHAL TUGAS KULIAH.

$\begin{array}{ll}\text { MEDK 1 } & : \text { Ape name niang? 'Apa namanya ini?' } \\ \text { MEDK 2 } & : \text { Buah. } \\ \text { MEDK 1 } & : \text { Buah ahe? 'Buah apa?' } \\ \text { MEDK 2 } & : \text { Rambutan } \\ \text { MEMS } & : \text { Bang cariin KLB Bang. } \\ \text { MEDK 1 } & : \text { Tadi? } \\ \text { MEMS } & : \quad \text { Tadi itu bencana. Tadi dah masuk situ } \\ & \end{array}$

Pada penggalan tuturan di atas terdapat alih kode yang disebabkan oleh hadirnya orang ketiga yang ikut dalam proses pertuturan. Pada awalnya Penutur pertama dan penutur kedua menggunakan kode tutur Dayak Kanayatn. Namun, pada saat proses pertuturan antara penutur pertama dan penutur kedua berlangsung, penutur ketiga hadir. Penutur ketiga hadir dan langsung ikut dalam proses pertuturan dengan menggunakan kode tutur Indonesia. Penutur ketiga hadir dengan menanyakan kepada penutur pertama perihal tugas kuliah yaitu Bang cariin KLB (Kejadian Luar Biasa) Bang. Kemudian pada penutur pertama merespon hadirnya penutur ketiga dengan menjawab Tadi? jika dalam kode tutur Dayak Kanayatn dijah. Dengan demikian penggalan tuturan di atas mencerminkan bahwa hadirnya orang ketiga dalam proses pertuturan yang berlainan etnis dapat mengalihkan kode yang digunakan dalam proses pertuturan. Alih kode yang dilakukan bertujuan untuk menjelaskan terhadap pertanyaan mitra tutur sebelumnya. Hal tersebut didukung dengan hasil wawancara dengan penutur yaitu mahasiswa etnis Dayak Kanayatn 1. Penutur memberikan keterangan bahwa alih kode yang dilakukannya bertujuan untuk menjelaskan kepada penutur sebelumnya yang menanyakan perihal tugas kuliah.

Faktor penyebab alih kode yang disebabkan oleh pokok pembicaraan terdapat pada data berikut. Pada data tersebut terjadi percakapan antara tiga orang mahasiswa di aula STKIP Singkawang pada hari Senin, 10 April 2017 sekira pukul 13.00 WIB. Dua orang mahasiswa berasal dari etnis Dayak Kanayatn dan satu mahasiswa berasal dari Melayu Sambas.

$\begin{array}{ll}\text { KONTEKS : } & \text { PADA HARI SENIN, } 10 \text { APRIL } \\ & \text { 2017, SEKITAR PUKUL 13.00 WIB } \\ & \text { DI AULA KAMPUS TERJADI } \\ & \text { PERTUTURAN ANTARA DUA } \\ & \text { ORANG MAHASISWA YANG } \\ & \text { BERASAL DARI ETNIS DAYAK } \\ & \text { KANAYATN DAN SATU ORANG } \\ & \text { MAHASISWA BERASAL DARI }\end{array}$




\section{ETNIS MELAYU SAMBAS, MEREKA MEMBICARAKAN PERIHAL TUGAS KULIAH.}

$\begin{array}{ll}\text { MEDK } 1 & : \text { Ape name niang? 'Apa namanya ini?' } \\ \text { MEDK 2 } & : \text { Buah. } \\ \text { MEDK 1 } & : \text { Buah ahe? 'Buah apa?' } \\ \text { MEDK 2 } & : \text { Rambutan } \\ \text { MEMS } & : \text { Bang cariin KLB Bang. } \\ \text { MEDK 1 } & : \text { Tadi? } \\ \text { MEMS } & : \quad \text { Tadi itu bencana. Tadi dah masuk situ } \\ & \text { ya. }\end{array}$

Pada penggalan tuturan di atas terdapat alih kode yang disebabkan oleh berubahnya topik pembicaraan. Pada awal pertuturan, penutur pertama menanyakan kepada penutur kedua perihal buah-buahan. Penutur pertama menggunakan kode tutur Dayak Kanayatn, karena penutur pertama tahu bahwa penutur kedua berasal dari etnis yang sama yaitu etnis Dayak Kanayatn. Pada saat proses pertuturan antara penutur pertama dan kedua berlangsung, penutur ketiga yang berlatar belakang etnis Melayu Sambas menanyakan kepada penutur pertama perihal tugas kuliah yaitu Bang cariin KLB (Kejadian Luar Biasa) Bang. Pada penggalan tuturan tersebut mencerminkan perubahan topik pembicaraan. Topik awal pembicaraan yaitu perihal buah-buahan kemudian berubah topik perihal tugas kuliah. Alih kode yang dilakukan oleh penutur bertujuan untuk menjelaskan perihal topik pertuturan. Hal tersebut didukung dengan hasil wawancara dengan penutur yaitu mahasiswa etnis Dayak Kanayatn 1. Penutur memberikan keterangan bahwa alih kode yang dilakukannya bertujuan untuk menjelaskan apa yang ditanyakan oleh penutur sebelumnya. Penutur juga memberikan keterangan bahwa mitra tuturnya adalah teman sekelasnya.

\section{IV.SIMPULAN DAN SARAN}

\section{SIMPULAN}

Lingkungan kampus STKIP Singkawang Kalimantan Barat merupakan masyarakat yang multietnis. Hal tersebut dikarenakan latarbelakang etnis yang beragam, yakni terdiri dari dua etnis mayoritas: etnis Melayu Sambas dan etnis Dayak Kanayatn dan etnis dua ernis minoritas: etnis Jawa dan Madura. Masing-masing etnis yang berada di lingkungan kampus tersebut memiliki kode tutur yang berbeda-beda. Dengan demikian, lingkungan kampus STKIP Singkawang dapat dikatakan selain masyarakat multietnis juga merupakan masyarakat yang multilingal. Kondisi masyarakat yang multietnis dan mutilingual menyebabkan penggunaan kode tutur akan menjadi lebih bervariasi, khususnya dalam peristiwa tutur ragam informal. Kebervariasian kode tutur pada konteks informal lebih dipegaruhi oleh situasi dan konteks yang mengiringi tuturan tersebut.

\section{SARAN}

Penelitian ini merupakan penelitian eksploratif yang menggali masalah alih kode dan campur kode dan representasi kekuasaan dan solidaritas pada masyarakat multilingual di STKIP Singkawang Kalimantan Barat yang jangkauannya cukup luas. Oleh karena itu, penelitian ini masih perlu diperdalam lagi dengan penelitian yang serupa namun memiliki ruang lingkup yang lebih sempit. Hal ini perlu dilakukan agar dapat mencapai hal yang lebih mendasar.

Bagi mahasiswa di linglingkugan STKIP Singkawang Kalimantan Barat, bahwa peristiwa alih kode dan campur kode adalah peristiwa yang sering terjadi dalam komunikasi sehari-hari. Namun, sebagain besar tidak menyadari adanya fenomena tersebut. Hal ini bukanlah sesuatu yang negatif jika penutur mampu menempatkan diri dengan siapa dia berkomunikasi. Melalui penelitian tentang alih kode dan campur kode bagi mahasiswa di lingkungan STKIP Singkawang disarankan mampu menempatkan diri dengan siapa dia bicara dan dengan tujuan apa dia bicara.

\section{DAFTAR PUSTAKA}

Chomsky, N. (1957). Syntactic Structures. The Hague: Mouton.

Gumprez, J, J. (1977). The Sociolinguistic Significance of Conversational Code Switching. RESC Journal.

Kridalaksana, H. (2005). Bahasa dan Linguistik. Depok: FIB UI.

Matras, Y. (2009). Language Contact. Cambridge: Cambridge University Press.

Sudaryanto. (2015). Metode dan Aneka Teknik Analisis Bahasa. Yogyakarta: University Press.

Sugiyono. (2015). Metode Penelitian Pendidikan. Bandung : Alfabeta.

Sumarsono. (2007). Pengantar Semantik. Yogyakarta: Pustaka Pelajar.

Sutopo, H, B. (2002). Metodologi Penelitian Kualitatif: Dasar Teori dan Terapannya dalam Penelitian. Surakarta: UNS Press.

Suwito. (1985). Sosiolinguistik. Surakarta: UNS Press.

Undang-Undang Dasar Negara Republik Indonesia. Tahun (1945). Pasal 36.

Wardhaugh, R. (1986). An Intriduction to Sosiolinguistics. Australian: Blackwell Publishing. 